\title{
Values Education in Science Lessons with Activities: Responsibility Value
}

\author{
Havva Yaman ${ }^{1 *}$, Burcu Anilan ${ }^{2}$ \\ ${ }^{1}$ Fatih Faculty of Education, Department of Mathematics and Science Education, Trabzon University, Trabzon, Turkey, ${ }^{2}$ Faculty of Education, \\ Department of Mathematics and Science Education, Eskisehir Osmangazi University, Eskisehir, Turkey
}

*Correspondence Author: yamanhavva9326@gmail.com

\section{ABSTRACT}

This research aimed to gain the value of responsibility implicitly through activity-based values education tasks (ABVET) prepared in secondary school science lessons. The research was carried out with the embedded quasi-experimental design, one of the mixed research methods. The study group of the research consisted of 37 middle school students in total. Non-parametric tests were used to analyze the quantitative data obtained within the scope of the research and descriptive analysis was used in the analysis of qualitative data. The Dilemma Situations Form (DSF) developed by the researchers, activity documents, student and researcher diaries, and focus group interview form was used as data collection tools. Lessons were taught in the control group as curriculum in practice. In the experimental group, lessons were taught by the researchers with an enriched content and activity program aimed at gaining responsibility value. It was concluded that there was a significant difference in favor of the experimental group between the post-test scores of the experimental and control groups. It was concluded that ABVET was effective in gaining responsibility value to sixth grade students with the data obtained from the DSF, activity documents, student and researcher diaries and focus group interview form. This research shows which method, technique, and material can be preferred for values education in science courses included in education programs. Given the promising results of the current research, methods or techniques related to the constructivist approach such as the appropriate values education program, ABVET should be used for different science subjects, various courses, and grade levels in future studies.

KEY WORDS: activity-based values education; science education; responsibility value; values; values education

\section{INTRODUCTION}

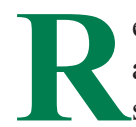

ecently, rapid changes and developments in science and technology have caused direct changes in society's needs and the individual's role in society (MoNE, 2018). While these changes and developments have increased the quality of life, they have also introduced sociological and cultural changes in the social structure. These changes in social structure have caused social problems. Some of these problems are intolerance, irresponsibility, and the decline of the institution of the family (Kenan, 2009; Lickona, 2009). All individuals in society, especially children are affected by these problems and this causes a decrease in social and moral standards values. Thus, it has been argued that education is important and some problems can only be resolved through education (MoNE, 2018). At this point, to attain values through education, the concept of "values education" becomes crucial (Halstead and Taylor, 2000). Although, values education and moral education concepts are sometimes interchanged, values education is used as an inclusive concept that involves concepts such as character education, moral education, and citizenship education (Halstead, 1996). All kinds of activities in schools which help students develop or learn morality and values are often referred to as values education (Halstead, 1996; Lovat, 2011;
Powney et al., 1995). Though values are obtained from family and society, teachers and school are the ones who carry it out scientifically, systematical, planned, and purposefully. Schools and teachers can be successful in values education as they transfer the value gain, which means to transform it into behavior in students' lives.

The relevancy of the values education with real life and an environment that enables individuals to participate actively is crucial for internalization of the values by the individuals and transforming them into behaviors. In this respect, the progressive or constructivist approach becomes prominent in effective and purposeful practicing values education (Brown et al., 2019). The constructivist approach advocates the active construction of students' moral understanding through social interaction and moral discourse processes (Solomon et al., 2001). Reasoning and scientific explanations, discussions about dilemmas with moral dimensions and the use of individuals' decision-making processes are considered as methods that can be applied for this approach (Power et al., 1989). The moral judgments of the students can be revealed by giving them moral dilemma stories (Berkowitz, 2011; Narvaez, 2006). It is considered that values education can be carried out with student-centered active learning techniques that will attract students' attention to a specific value and enable them 
to think about that value and reveal the values that they already have (LVE, 2012). Activity-based values education tasks (ABVET) are practice-oriented tasks that allow the student to behave more freely in the learning environment and to be at the forefront with the activity performed (Superka et al., 1976). Therefore, it is predicted that it will be an effective method to gain values using ABVET within the scope of the constructivist approach (LVE, 2012).

One of the most crucial values that can be gained by students is responsibility value. Due to the reflection of adverse events in the society on schools, the importance of responsibility is increasing day by day among the values that individuals desire to gain. Lickona (2009) defines responsibility as individuals taking care of themselves and other people, assuming their duties, participating in social life, working to correct problems and making efforts for a better life by taking responsibility in the moral dimension. The environment has a great impact on gaining responsibility value. To develop a sense of responsibility, students should be raised in an environment where they can take responsibility, make their own decisions and take the consequences of their actions (Burke et al., 2001). The first place to gain this is from the family, then the school (Tekbiyık and Akdeniz, 2017).

In the related literature, some research has investigated how values education processes (Cohen, 2006; Davidson et al., 2008; UNESCO, 2002) or how students transfer values to daily life (Duer et al., 2002; Gao, et al., 2019; Gibson and Landwehr Brown, 2009; Kropp, 2006; Lee et al., 2013; Thornberg, 2008). Studies on values education in the literature are generally limited to behavioral sciences (Tekbiyık and Akdeniz, 2017). However, it should be known that value teaching for students is not a problem that can be solved with a single lesson or discipline, or a job that can be done with only one lesson (LVE, 2012). Scientific and ethical values and social values are included in the learning outcomes of the Science Curriculum (MoNE, 2018) and values education should be addressed in every discipline (UNESCO, 2002). Science education is also a part of daily life by its nature, and values and scientific ideas are closely linked in the human mind (Grace and Ratcliffe, 2002). Therefore, students should have the values that affect every aspect of life to solve the problems they encounter in daily life. Insufficient studies on values in science education increases the need for qualified studies in the field of values education. Therefore, we expect this research to be carried out for values education within the scope of science lesson to fulfill the mentioned need. In this research, the effect of ABVET, which was prepared within the scope of "Matter and Heat" subject to students in science, on gaining responsibility value was examined and answers were sought for the following questions.

- Is ABVET effective in gaining responsibility value in sixth grade students?

- What are the opinions of sixth grade students concerning ABVET?

\section{METHODOLOGY}

This research aimed to gain the value of responsibility implicitly with ABVET, which was conducted with the embedded quasiexperimental design, one of the mixed research methods. The purpose of the mixed method is to combine qualitative and quantitative research techniques, methods, approaches, or concepts and presents them in a single frame. The use of quantitative data to answer the basic question of the experimental design, and also the use of qualitative data to answer the other question in the research about the experimental process before, after or during the implementation process are explained by the embedded experimental model (Creswell and Plano Clark, 2017). Quantitative data were collected before and after the implementations with ABVET, and the pre-testpost-test control group quasi-experimental process was carried out in 6 weeks. The qualitative data obtained during and after the implementation process were used to reveal students' real views and behaviors, and determine the reasons for these views and behaviors.

\section{Participants}

The participants of the research consist of randomly picked sixth grade students. There are two groups in the research, which are experimental and control groups. Along with the examination of the information obtained from teachers and success tables to determine the experimental and control groups, it was discovered that the class branches showed high similarities in terms of academic success and the groups were equivalent. A total of 37 students, 20 students (nine girls and 11 boys) in the experimental group and 17 students ( 9 girls and eight boys) in the control group, participated in the research. Permission was obtained from the relevant institutions to carry out the research. It is taken into consideration that the school administration and the teacher have a positive view on the application of ABVET with value content. All students were informed about the process in advance. Parents of the participants were informed about the research and the "parent consent form" was signed.

\section{Data Collection Tools}

Research data were collected before, during, and after the implementation using data collection tools. Data were collected with the Dilemma Situations Form (DSF), structured student diary, researcher diary, activity documents, and semi-structured focus group interview form, all of which were prepared by the researchers.

DSF has been developed by the researches using the literature (Aktaş and Bozdoğan, 2016; Herdem, 2016; Iscan and Senemoglu, 2009; Kohlberg, 1975; Kunduroğlu and Babadoğan, 2010; Lickona, 2009; LVE, 2012; Superka et al., 1976; Trevino, 1992; Veugelers, 2000) and considering the purpose of the research. DSF consists of eight questions; includes short stories about the value of responsibility for the subject of Matter and Heat. These short stories involve the students' situations whether they take precautions in the use of energy resources, fulfill the responsibilities for saving energy at 
home, take on responsibilities in purchasing electronic devices, feel responsible for the society, be sensitive to environmental problems or not. First, students analyze the situation by discussing the presented case in DSF then they were requested to put themselves in the shoes of the protagonists in these stories. After each story students received the question; “ “... what would you do if you were in the position of him/her?" Two different options were created as showing the value or not showing the value and students were asked to mark the option that suits them. After each option, the expression "because" was given and students were asked to explain the option they chose. The four situations in the DSF are in Appendix A.

\section{The Validity and Reliability of the Research}

The DSF, structured student diary, researcher diary, activity documents, and semi-structured focus group interview form were created and based on the literature to ensure the internal validity. The data collection tools were reviewed by experts in the field and amended in accordance with their opinions and suggestions. The DSF and activity documents were piloted with 20 students similar to the participant group. The DSF and activity documents were finalized by evaluating the questions asked by the participants during the application, the answers given by the students, the clarity and comprehensibility of the stories, the reflection of the value, the suitability of the student level, and making various corrections. The data obtained to ensure the external validity of DSF and the expressions of the experimental group students were examined and described in detail. To ensure the scoring reliability in DSF, three expert opinions were consulted. The number of consensus and disagreement was determined in the comparisons and the reliability of the research was calculated using Miles and Huberman's formula (Reliability $=$ consensus/agreement + disagreement). It was observed that the scoring made by the researcher and three experts was $94 \%$ consistent (Miles and Huberman, 2015).

Data triangulation was made by collecting research data with qualitative and quantitative data. The researchers consulted the field experts in the development of all data collection tools, in the analysis of raw data and received feedback from field experts in order to meet the verifiability criterion. To meet the transferability criteria of the research, direct quotations are frequently used. The obtained findings are presented with the support of the literature related to the comments.

\section{Implementation and Data Collection Process}

The DSF was applied to the control and experimental groups as a pre-test. Then, the control group lessons were taught as determined by the curriculum. In the experimental group, an enriched content and activity tasks designed by the researchers for the present research and these tasks were applied to gain responsibility value. The tasks and their contents are given in Table 1.

ABVET was implemented within the scope of the "Matter and Heat" unit for 6 weeks. Student diaries prepared in accordance with the content of the task were filled in by the students at the

\begin{tabular}{|c|c|}
\hline ABVET & The Objectives of ABVET \\
\hline $\begin{array}{l}\text { Catch-phrase } \\
\text { preparing task }\end{array}$ & $\begin{array}{l}\text { A text on thermal insulation was given to the students and } \\
\text { they were asked to create a slogan according to this text. }\end{array}$ \\
\hline Drawing task & $\begin{array}{l}\text { Students were asked to draw a picture after the } \\
\text { activities relevant to thermal insulation, energy and } \\
\text { energy saving. }\end{array}$ \\
\hline $\begin{array}{l}\text { Reading text and } \\
\text { answering the } \\
\text { questions task }\end{array}$ & $\begin{array}{l}\text { The students were given a text on thermal insulation } \\
\text { in buildings, their contributions to family and national } \\
\text { economy and energy saving, and they were asked to } \\
\text { answer the questions asked. }\end{array}$ \\
\hline $\begin{array}{l}\text { The comparison } \\
\text { of energy guide } \\
\text { labels task }\end{array}$ & $\begin{array}{l}\text { The students were asked to make a selection by } \\
\text { comparing the information between the two water } \\
\text { heaters that emphasize what should be considered } \\
\text { when purchasing electronic devices and whose features } \\
\text { are given. }\end{array}$ \\
\hline $\begin{array}{l}\text { The energy } \\
\text { sources that I } \\
\text { use in a day task }\end{array}$ & $\begin{array}{l}\text { Students were expected to mark the electrical appliances } \\
\text { they used in a day and calculate the total energy money } \\
\text { they used according to the table showing how much } \\
\text { "energy money" they spent. Then, they were asked how } \\
\text { they would change their behavior to reduce their total } \\
\text { energy costs by "10 energy money." }\end{array}$ \\
\hline $\begin{array}{l}\text { Story } \\
\text { completion task }\end{array}$ & $\begin{array}{l}\text { Students were asked to complete the incomplete story } \\
\text { about the importance of electricity in our lives }\end{array}$ \\
\hline $\begin{array}{l}\text { Energy use at } \\
\text { home task }\end{array}$ & $\begin{array}{l}\text { It was aimed for students to learn about energy use at } \\
\text { home and to determine whether family members fulfill } \\
\text { their individual responsibilities by observing the home } \\
\text { environment. }\end{array}$ \\
\hline $\begin{array}{l}\text { Energy } \\
\text { investigator task }\end{array}$ & $\begin{array}{l}\text { It was stated that the students worked as energy } \\
\text { detectives in their homes to use energy efficiently and } \\
\text { they were given two tasks to fulfill. }\end{array}$ \\
\hline $\begin{array}{l}\text { Preparing a } \\
\text { poster task }\end{array}$ & $\begin{array}{l}\text { Students were asked to prepare posters by doing group } \\
\text { work on the subject of processed fuels and energy } \\
\text { resources. }\end{array}$ \\
\hline Photograph task & $\begin{array}{l}\text { Students were asked to answer the questions and } \\
\text { photos given about the group subject. }\end{array}$ \\
\hline $\begin{array}{l}\text { Preparing a } \\
\text { public service } \\
\text { announcement } \\
\text { task }\end{array}$ & $\begin{array}{l}\text { Students were asked to prepare an informative public } \\
\text { service announcement on heat insulation and energy } \\
\text { saving, energy consumption, energy resources, and } \\
\text { fuels to be broadcast on television channels. }\end{array}$ \\
\hline
\end{tabular}

end of each task. Both activity documents and student diaries were collected by the first researcher at the end of each task. The first researcher also kept the diary after the activities and the data were enriched by taking photographs, audio, and video recordings in certain parts of the practices performed in the lessons. After the implementation process was completed, DSF was applied to the experimental and control groups as the post-test, and then the focus group interviews were conducted with the experimental group students by taking audio and video recordings.

\section{Data Analysis}

The data obtained as a result of the responses to the DSF were scored (zero point-not applicable for the responsibility value gaining and one point-applicable for the responsibility value gaining) and transferred to SPSS 20.0TM for statistical analysis. Since the number of students in the experimental and control groups was less than 30 , nonparametric tests were used. The Mann-Whitney U-test was used to compare the average 
of the experimental and control group students in terms of gaining responsibility value, and the Wilcoxon test was used to compare the pre-test and post-test measurements in accordance with quantitative data of the DSF. The qualitative data obtained from the DSF, activity documents, student diaries, researcher diary, and semi-structured focus group interview form were analyzed descriptively and direct quotations were included in the study. After the implementation, the focus group meeting was held with the students. Each interview lasted between 25 and $33 \mathrm{~min}$.

\section{RESULTS}

\section{Findings Concerning the First Research Question}

The findings are in regard to the effectiveness of ABVET in gaining responsibility value to sixth grade students as a result of the analysis of quantitative data obtained from the DSF pre-test and post-test scores. In addition, students' expressions were also included along with the quantitative data from DSF to identify the gains regarding the value of responsibility. The comparison of the pre-test scores of the experimental and control group students with the Mann-Whitney U-test is given in Table 2.

According to Table 2, although there was no significant difference between the pre-test scores of DSF applied to the groups before the instruction intervention $(U=121.50 ; \rho>.05)$, there is a significant difference between the post-test scores in favor of the experimental group $(U=104.50 ; \rho<.05)$.

According to Table 3 , while there was a statistically significant difference between the DSF pre-test and post-test scores

\begin{tabular}{|c|c|c|c|c|c|c|}
\hline Test & Group & $\mathrm{N}$ & $\begin{array}{l}\text { Mean of } \\
\text { Ranks }\end{array}$ & $\begin{array}{l}\text { Sum of } \\
\text { Ranks }\end{array}$ & U & p \\
\hline \multirow[t]{2}{*}{ Pre } & Experimental & 20 & 16.58 & 331.50 & 121.50 & 0.129 \\
\hline & Control & 17 & 21.85 & 371.50 & & \\
\hline \multirow[t]{2}{*}{ Post } & Experimental & 20 & 22.28 & 445.50 & 104.50 & 0.041 \\
\hline & Control & 17 & 15.15 & 257.50 & & \\
\hline
\end{tabular}

\begin{tabular}{|c|c|c|c|c|c|c|}
\hline Group & Test & $\mathbf{N}$ & $\begin{array}{c}\text { Mean of } \\
\text { Ranks }\end{array}$ & $\begin{array}{l}\text { Sum of } \\
\text { Ranks }\end{array}$ & $z$ & p \\
\hline \multirow[t]{3}{*}{ Experimental } & $\begin{array}{l}\text { Negative } \\
\text { Rank }\end{array}$ & 0 & 0 & 0 & $-3.652 *$ & 0.000 \\
\hline & $\begin{array}{l}\text { Positive } \\
\text { Rank }\end{array}$ & 17 & 9.00 & 153.00 & & \\
\hline & Ties & 3 & & & & \\
\hline \multirow[t]{3}{*}{ Control } & $\begin{array}{l}\text { Negative } \\
\text { Rank }\end{array}$ & 0 & 0 & 0 & $-1.633^{*}$ & 0.102 \\
\hline & $\begin{array}{l}\text { Positive } \\
\text { Rank }\end{array}$ & 3 & 2.00 & 6.00 & & \\
\hline & Ties & 14 & & & & \\
\hline
\end{tabular}

*Based on negative rank of the experimental group students in favor of the post-test scores $(z=3.652, \rho<.05)$; there was no significant difference between the pre-test and post-test scores of the control group $(z=1.633, \rho>.05)$. Furthermore, the effect size for Wilcoxon signed-rank test of experimental group was found to be 0.82 , which fell into a large effect-size. In DSF, which was applied in order to support the data obtained from the quantitative data, demonstrates the responsibility value gains in the pre-test and post-test obtained from the students' expressions in DSF are presented below.

In one of the dilemma situations in the DSF (see first dilemma in Appendix A), it was seen in the expressions that students generally made statements about saving in the pre-test. S5 expressed that "Saving is more important than anything" and S20 stated "I would have done something good and saved at the same time. It doesn't matter if I am late for the school bus. "In the post-test, it was observed that this increase continued, but they gave more statements to prevent waste. In the post-test, S5 stated "That light will be on until evening. It would be more profitable to turn off the light than missing the school bus" and S1 expressed "So that we don't waste electric otherwise there will be environmental and air pollution."

In another dilemma situation (see second dilemma in Appendix A), the pre-test expression of S5 "even though the b lamp is costly, it is a long-lasting source of light" shows that they mention only the financial contribution or, it can be seen in S1's "I would buy it because it is long-lasting" expression that they make an evaluation between the two lamps in terms of "quality" or "usefulness". In the post test, S10's "I would pay a lot of money when I first bought, I wouldn't have to pay for a longer time, it would have saved more" or S19's "Because of the high cost of electricity in lamp A, B lamp is more profitable and useful" expressions demonstrate that students made explanations by considering not only financial contribution but also other characteristics and making associations between the features as the reason for the justification in their statements. On the other hand from S1's "B lamp is more economical. We will pay more now, but I would pay less in the future because it's economical" expression it can be understood that they feel responsible for their choices.

In third dilemma (see Appendix A) pre-test, S12's "it would be a waste to run the machine again for that little laundry" or S11's "there is no need to run the machine for just one piece of laundry" expressions show that students emphasize energy waste. In the post-test, S10's "I would cover it if it were a small stain and wear it anyway. It would be a waste" statement shows that they hold themselves responsible for the energy waste. It can be understood from S18's statement "I would say that it would be okay to go to school with a dirty track suit just once" that they give statements to take on their responsibilities.

The fourth dilemma (see Appendix A) pre-test, S2 stated "so that the house would get warm," and S4 "there is no place at home I don't want it to cover the heater" in the post- test 
students'. Post-test statements were as follows, S6 “it would prevent us from getting warm. The heat and our money would be wasted. It would be better than freezing to put the couch in the basement" and S12 "It would be a waste to put it in front of the heater. I would put it even if it had emotional value."

In general, from the students' statements to the dilemma situations it can be understood that; in the pre-test, students' statements were limited to a certain justification, and their expressions in the post-test were effective both scientifically and in terms of internalizing the responsibility value of the students. It is also seen that they emphasized the importance of individual responsibility.

Regarding the first research question, in addition to the findings regarding dilemma situations, documents obtained from ABVET, qualitative findings obtained from student and researcher diaries are presented below.

The catch-phrases formed by the groups to determine the relationship between thermal insulation and responsibility in the catch-phrase preparing task are given in Figure 1.

In addition, it can be seen that S8's statement in their diary "I think creating catch-phrases will be a warning for the people, also we said that the catch-phrase should be good so that people can understand." S8 cared about attracting people's attention and S8 took responsibility as the student made effort to create a nice catch-phrase. Students created their catchphrases in group work. Students made the following statements S12 "everyone contributed to the project" and S14 "Everyone participated and focused on the catch-phrase, it was nice and fun" expressing that during the group project, group members took responsibility.

The students were asked to draw a picture about one or more of the topics covered in the unit. The benefits of thermal insulation, the precautions to be taken in thermal insulation, energy saving methods, the duties and responsibilities of people for energy saving were listed and they were asked to draw a picture dealing with one or more of these topics.

The student with the S6 code name included these statements about the picture S6 drew in their diary:

I considered how I can give an example to draw savings... In the first picture I draw a person who unplugs the iron to iron the rest of the clothes. In the second picture I showed a person who runs the dishwasher because it is full... In the last one the man goes to dinner but turns off the TV from the push-button instead of the remote control. I thought of saving when I drew these... Unless these actions are taken there will be economic loss. Both in our country and family.

S6 got the subject of energy saving and taking responsibilities by demonstrating in their picture incorrect behaviors. Similarly, it can be seen from S12's statement:

...In my environment people don't think about how the electric is produced. When we are not careful about these, air pollution happens in our lives. I wanted to attract attention by drawing this picture because most people don't know this.

This student wanted to take responsibility in informing people about the importance of the effect of energy production on environment (See Figure 2).

The students were asked to read the text and answer the questions in the reading task about the text. S6 "Hale should adjust the heater at a lesser degree instead of turning it off during the day;" S12 "Hale shouldn't turn off the heater, he should move the furniture in front of the heater and keep the curtain open;" and S4 "I have learned the importance of heat

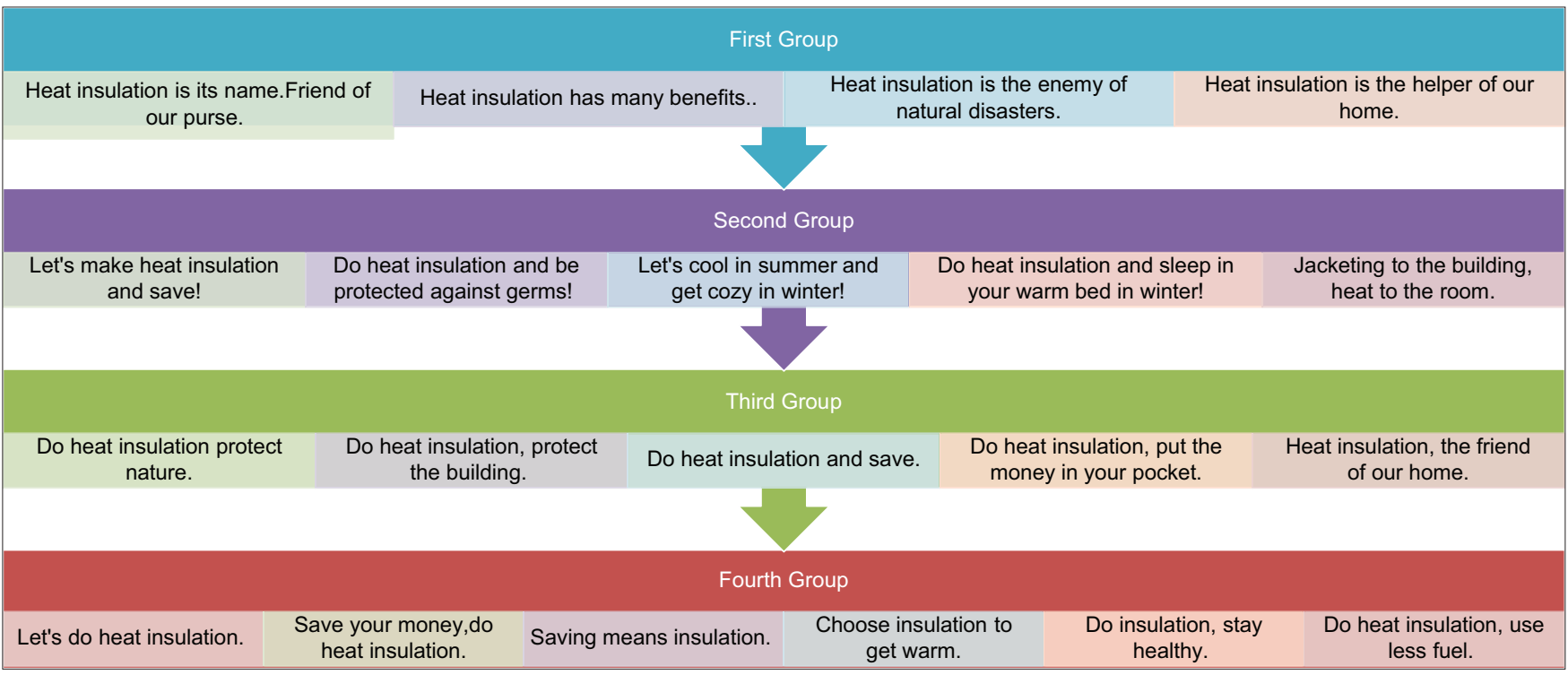

Figure 1: Catch-phrases created by the students in the catch-phrase preparing task 
insulation in terms of economy and heat. I will inform the people around me about heat insulation from now on." It can be understood from these statements that the students were aware of the precautions they should take for heat insulation at home. In addition, the fact that they mentioned they were conscious about this subject and they would also educate the people around themselves could be explained as taking their responsibilities.

In the comparison of energy guide labels task S5's statement "I have learned the annual cost and amount of energy a device used. Now we should buy something we want according to the cost, durability, annual cost and performance" expressed that they would pay attention to the purchase of electronic devices, and they were aware of why they should pay attention. Students finished the task with the group project. S17 stated that "We worked together and learned that we can do any work. I have realized that there is trust when I am with my friends" and emphasized that all the students discharged their responsibility in the group project. In this respect, it could be said that group work was indirectly effective in realizing their responsibilities.

In the energy sources I use during the day task, students stated that they realized the importance of saving and the mistakes in the use of electronic devices, they should save and they became conscious about this in the following way. S9 "For example it can be an energy saving lamp, I can inform the people around me, I can use less water. I think I have learned the importance of using consciously" and S10 "We learned that we should use less electricity. We learned how much all the devices use. We learned the importance of saving." In addition, the researcher also observed that during the activity, the students became aware of their responsibilities regarding the subject from their statements, attitudes, and facial expressions in their presentations.

From the statements in the student diaries to the story completion task, it was seen that the students generally felt responsible for saving electricity, that everyone should change their behaviors, and they were worried about this. S6 commented:

... I cannot call and text my friends who are away from me if there is no electricity. I cannot do my homework; books cannot be published and I cannot read them. I cannot play the guitar. Ohhh! It's a good thing that there is electricity!

The researcher stated in her diary "As the students complete their stories Özgür asked; "the classroom is bright enough can I turn off the lights?" and I let him. I think Özgür's behavior sets an example". This question by the student shows that the student had gained a sense of responsibility and turning off the lamps was his responsibility. In addition, it can be said that student behavior is important for classmates to realize their responsibilities.

In the energy use at home task S9 "I will control all the electric devices at home from now on" and S20 "I started turning off electricity and water when I am at home. I started to warn my family." The statement in the researcher's diary "Today when Hasan said that their neighbor's balcony light is always on and only sometimes do they turn it off, he expressed that he is uncomfortable with this situation" demonstrates that the student observed his environment and he was aware whether other people in his environment were taking responsibility or not.

In energy investigator task, students took responsibility as energy inspectors. S10 noted:

I observed my family during the week and checked whether my family saves or not. Actually my parents save and advise us to save as well. My siblings are not so careful about it. They both keep the light on when they leave the room. I warn them to turn it off, but they don't care. This makes me upset. I haven't found a solution to this problem.

In this statement, it was seen that they determined whether individuals fulfill their individual responsibilities that family members feel uncomfortable due to their wrong behaviors and feel responsible for this situation. S5

I placed a little card on each item that wastes uses energy. These cards are red because red symbolizes energy use... I explained plainly how to save. I warned them when I saw them waste. My family is now doing 1-2 of what they do in a week and they care about it now.

In this statement, it can be seen that students changed their families' behavior and they were careful about making it permanent; and they transferred it into behavior.

Students were asked to make a poster about the subject in a group activity. The student with S12 as a code name stated "I made it as I thought about what causes environmental pollution. A person who takes a look at the poster can see what causes environmental pollution and wouldn't do it again." This statement indicated that he prepared the post as he considered himself responsible for warning others.

S19's statement:

I was careful about drawing the causes of environmental pollution. There are a lot of things that pollute the environment such as smoke, exhaust, and house chimney. At least a person who looks at this picture can understand that he/she should warn them.

From this statement, it can be understood that the student wanted to emphasize that a person who examined the picture should take responsibility in warning others (See Figure 3).

In the photographs task saving team group in their evaluation report:

These photographs prove how the world is not beautiful and shiny. This causes light pollution. We saw that nobody saves or cares about the nature... the smoke that comes out of factory chimney, exhaust gas, too much use of fossil fuels cause climate change and global warming. Global 
warming causes the decrease in the number of living species. This also hurts us.

In this statement, these students mentioned their responsibilities for the environment and emphasized the consequences if those responsibilities were not taken. S6 in their diary mentioned " $I$ don't think our world is bad. I think we live in a bad world. Unfortunately, we are the reason for that! We should protect the environment from now on!" In this statement, the student was aware of the environmental problems and stated that he would fulfill his responsibilities.

Students stated concerning the task of preparing a public service advertisements such as S10's "This is very beneficial we get information with our friends and also other people in our environment, everybody learns how to save," and S9's "They can learn how to use the energy sources properly from here they can learn how to save with this digital story, " and finally S6's "We warn people preparing things such as advertisements" these statements show that they suggested it to their friends. They drew attention to the need for them and their friends to take responsibility by preparing a public advertisement.

\section{Findings Concerning the Second Research Question}

In this section, findings related to the research problem for determining the opinions of sixth grade students regarding ABVET are presented. Students' opinions after the focus group meeting regarding the activities aimed at gaining responsibility value were collected under a single main theme under five subcategories as "Reflections of ABVET to the students." Five sub-themes determined under this theme are given in Figure 4.

Representative student statements under the theme of "Learning" are presented below.

S9 "Based on this information, I learned something. When there is air pollution, the rain in the air comes to the soil, the pollution in the soil then passes into the water, as it evaporates, it attracts living things to the air all the time and dies."

S10 ".the things we thought right were wrong. For example, we forget the plug in there is no phone to charge but the electricity is used anyway, instead of turning the TV off from TV button we should use its own push-button."

From the expressions of these students, it was seen that they learned in detail about the subject, mention saving and its importance and realize their mistaken behaviors.

The student expressions given below demonstrate how they have gained awareness of the subject with ABVET under the theme of "gaining awareness" and they were aware of why they should pay attention to these issues.

S1 “... For example, I did not pay much attention before, so I would leave the light on, but when I learned more, I realized that we should not keep it on"

S13 "There are too many cars, too much fuel is used, the lights are always on in the houses. There is global warming, living beings die."
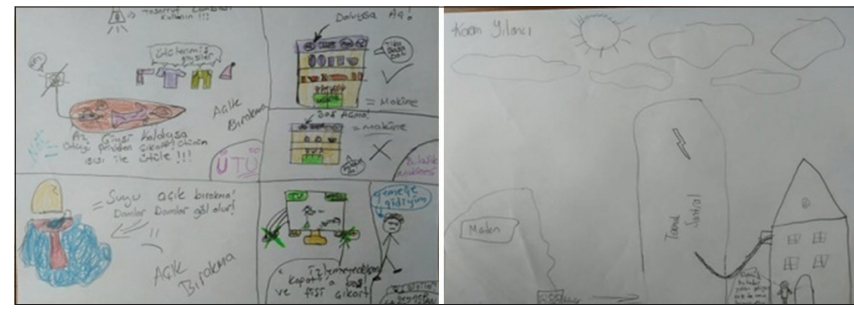

Figure 2: The drawings by $\mathrm{S} 6$ and $\mathrm{S} 12$
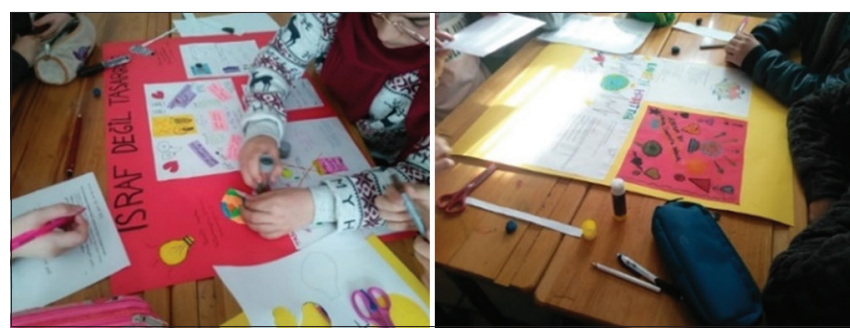

Figure 3: The drawings by $\mathrm{S} 12$ and $\mathrm{S} 19$

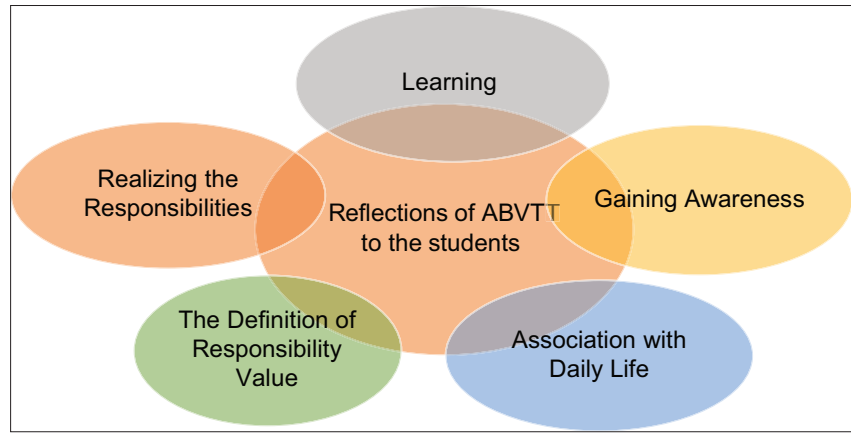

Figure 4: Data obtained from semi-structured interview form

Student expressions under the theme of 'relating to daily life', enabled students to think about their behaviors regarding school life, social life, and family life, and helped them to become a responsible person by changing their behavior.

S9 "I used to walk around the school corridors and see lights on, but I would never turn them off I would just walk by, now I turn them off."

S19 "There was a headman in our neighborhood. He changed the street lights with the ones that turn off in every two minutes. It turns off when there is nobody around."

S15 "We used to leave home without turning off the TV. Now I check before I go."

Students made a lot of definitions under the theme of 'defining the value of responsibility'. While some students stated the responsibility as their duty, they also defined it as the duties that all people should fulfill. In addition, they described it as a part of life and also mentioned the need for continuity of responsibility. Some of the statements of the students are as follows.

S5 "Responsibility is not only for one person but we should do it as a community. They are the things that everyone should do." 
S20 "Helping ourselves and other people, we teach and it's good for us as well."

S15 ".our responsibilities are the things that we should do all the time and repeat."

Finally, student representative statements under the theme of "realizing the responsibilities" are below.

S1 "For example I didn't use to care about it before and I would say it doesn't matter. For example, I didn't use to fulfill my responsibilities before I learned in the class."

S10" ...I didn't use to warn anyone before. Now everything is different. I warn my family about the things I 've learnt."

From the statements of the students, it was seen that the students cared and fulfilled their responsibilities, and they warned the people around them to be responsible by assuming their responsibilities.

\section{DISCUSSION}

In this research, it was aimed to gain the value of responsibility implicitly with ABVET, which was prepared for the secondary school science course. The effectiveness of ABVET in bringing responsibility value to sixth grade students and student views on the activities were described by associating them with the value of responsibility. Among the quantitative findings of the research, it was determined that there was a significant difference in favor of the experimental group between the post-test scores of the experimental and control groups. The DSF pre-test-post-test findings applied to the experimental and control groups show that there was a tendency toward the responsibility value of the students in the experimental group who performed the ABVET.

Moreover, it was concluded that this tendency is supported by the qualitative data obtained from DSF in the pre-test and post-test. As the reasons to the answers of the students in the experimental group in DSF were examined; whereas the expressions of students showing value tendency in the pretest were generally limited and shorter; in the post-test, it was seen that students increased the reasons for their answers and prefer positive opinions about value. It has been determined that they used richer and more varied expressions to show the characteristics of the value of responsibility, such as being aware of its role in society as a responsible citizen, being an active participant, and having the knowledge required to fulfill responsibilities. Regarding the statements of students in DSF before the implementation process, the students may have tended to exhibit the behavior expected from them or they wanted to get approval (Iscan and Senemoglu, 2009; Kelman, 1958). On the other hand, in the post-test, students adopted the promoted behavior may have been found useful by students and they tended to internalize responsibility because it gave a solution to the problem, or it answered the needs (Kelman, 1958). Therefore, it can be said that students used richer and more diverse expressions. This result is in line with the results reported in Iscan and Senemoglu's (2009) study, based on the interviews data with the experimental group students. The successful implementation of ABVET seems to increase students' responsibility awareness and allow them to understand the responsibility by associating this value with their real-life situations.

Findings obtained from activity documents, student and researcher diary showed that students internalized responsibility value and could make in-depth inferences about responsibility value. It was understood that they realized the effects of social responsibility and took responsibility together with individual responsibility on people and the environment. With ABVET students revealed their answers about what would happen if they had and do not have the value of responsibility by establishing a concrete daily life relationship. Similar to this research, the results of many studies on the value of responsibility in the literature also supported our research results (Duer et al., 2002; Gibson and Landwehr Brown, 2009; Gordon, 2010; UNESCO, 2002). For example, Burke et al. (2001) prepared a character education program on respect, justice, responsibility, citizenship, flexibility, helpfulness, and honesty, and integrated this program into the primary education program and they found that the character education program has positively affected student interaction. Despite the limited number of values education studies in science education, almost all of them emphasized the same results as this research (Aktaş and Bozdoğan, 2016; Herdem, 2016; Iscan and Senemoglu, 2009; Kunduroğlu and Babadoğan, 2010). The consistency of current study's findings with the findings of the other studies can be considered as an indication that such practices or programs are effective on values education. The positive developments in students' value of responsibility might happen because of the integration of this value in science teaching through ABVET (Cox, 1988; Halstead, 1996).

In the focus group meetings held after ABVET, students stated that thanks to ABVET, they learned many different subjects, corrected their erroneous knowledge, gained awareness on many issues such as energy saving, thermal insulation, and renewable energy resources. It is seen that students learn and adopt their responsibilities thanks to the activities associated with daily life on these issues. Most importantly, it has been determined that they observed people and directed them to take their own responsibilities. The students' definitions regarding the value of responsibility after the activities, expressing the changes in their thoughts and behaviors and giving examples from their lives are indicative of the achievement of the research in terms of gaining responsibility value. It is thought that ABVET gave these students the opportunity to discover the value of responsibility and develop this value according to their potential. At this point, the quality of values education becomes crucial. It is very important how values are given to students and which value will be given to students by which method and technique (LVE, 2012; Superka et al., 1976). For this reason, the theoretical framework of this research has 
been discussed within the scope of the constructivist approach (Beck and Kosnik, 2002; Solomon et al., 2001). Because the constructivist approach in values education advocates that the student actively constructs value using reasoning, scientific explanations, moral debates, and decision-making processes of individuals (Brown et al., 2019; Power et al., 1989). Therefore, it is thought that the creation of ABVET using a studentcentered and inquiry-based approach plays an important role in drawing students' attention to the value of responsibility and thinking on it, thus it is effective in gaining the targeted responsibility value of ABVET. The suggestion of Duer et al. (2002) on the effectiveness of classroom activities for the development of students' responsibility levels also supports the results of our research. In addition, it is known that UNESCO (1991) emphasizes the application of different but appropriate teaching techniques in values education.

In our research, it is thought that the reason for the positive development in the responsibility value of students is the result of integrating this value into science teaching with ABVET instead of directly presenting this value. Introducing values education into learning areas and leaving this to the implicit program is important for the sustainability of values education (Chowdhury, 2016; Gao et al., 2019; Kumarassamy and Koh, 2019). The best way to add value to students includes all stages of life. For this reason, it has been concluded that the implementation of ABVET or similar values education practices by associating the gains in the curriculum with daily life is effective.

\section{CONCLUSIONS AND IMPLICATIONS}

When the research was analyzed in a holistic way, it was seen that the application of ABVET to implicitly gain the value of responsibility contributed to the students increasing their sense of responsibility and gain the value of responsibility by associating this value with real life situations. The quantitative results were based on the DSF data, which was limited to the measured value. A more comprehensive form would cover each value addressed and the diversity for each value. Values education should be embedded in the whole of education life implicitly. When the values are considered inseparable from the society value integrated science education curriculum can be effective in adding value to students. As a result of this research, it can be said that positive results can be achieved by integrating values not directly but implicitly by students in science education (Cox, 1988; Halstead, 1996). Along with this, the importance that should be given to values education should be increased not only in social fields but also in science courses included in education programs. Given the promising results of the current research, methods or techniques related to the constructivist approach such as the appropriate values education program, ABVET should be used for different science subjects, various courses, and grade levels in future studies. The problems encountered in values education are mostly about the method and technique to be preferred and what kind of material to use. Therefore, this research shows which method, technique and material can be preferred for values education.

\section{ACKNOWLEDGMENTS}

This research was produced from an unpublished master's thesis at Eskişehir Osmangazi University, prepared by Havva Yaman under the advisor of Burcu Anilan and was supported by Scientific Research Projects Fund at Eskişehir Osmangazi University [project number 2018-2437].

\section{REFERENCES}

Aktaş, Z., \& Bozdoğan, A.E. (2016). The effect of activities integrated with science course "human and environment" unit on gaining mercy value of secondary school students. Journal of Values Education, 14(32), 39-57.

Beck, C., \& Kosnik, C. (2002). Components of a good practicum placement: Student teacher perceptions. Teacher Education Quarterly, 29(2), 81-98.

Berkowitz, M.W. (2011). What works in values education. International Journal of Educational Research, 50(3), 153-158.

Brown, E., Chen, D., Davies, I., Urbina Garcia, A., \& Munguia Godinez, I. (2019). Educating young people about society in China, England, Mexico and Spain: Similar approaches to values education from different contexts. Compare: A Journal of Comparative and International Education,

Burke, N., Crum, S., Genzler, M., Shaub, D. \& Seets, J. (2001). Building Character Education in Our Schools to Enhance the Learning Environment (ED453144). ERIC. Available from: https://www.files. eric.ed.gov/fulltext/ED453144.pdf.

Chowdhury, M. (2016). Emphasizing morals, values, ethics, and character education in science education and science teaching. Malaysian Online Journal of Educational Sciences, 4(2), 1-16.

Cohen, J. (2006). Social, emotional, ethical, and academic education: Creating a climate for learning, participation in democracy, and wellbeing. Harvard Educational Review, 76(2), 201-237.

Cox, E. (1988). Explicit and implicit moral education. Journal of Moral Education, 17(2), 92-97.

Creswell, J.W., \& Plano Clark, V.L. (2017). Designing and Conducting Mixed Methods Research. $3^{\text {rd }}$ ed. Thousand Oaks, California: Sage Publications.

Davidson, M., Lickona, T., \& Khmelkov, V. (2008). Smart and good schools: A new paradigm for high school character education. In: Nucci, L., \& Narvaez, D., (Eds.), Handbook of Moral and Character Education. Milton Park, Abingdon-on-Thames: Routledge. pp. 370-390.

Duer, M., Parisi, A., \& Valintis, M. (2002). Character Education Effectiveness (ED471100). ERIC. Available from: https://www.files. eric.ed.gov/fulltext/ED471100.pdf.

Gao, L., Mun, K., \& Kim, S.W. (2019). Using socioscientific issues to enhance students' emotional competence. Research in Science Education. Doi: 10.1007/s11165-019-09873-1.

Gibson, K., \& Landwehr Brown, M. (2009) Moral development in preparing gifted students for global citizenship. In: Cross, T., \& Ambrose, D., (Eds.), Morality, Ethics, and Gifted Minds. Berlin: Springer. pp. 301-312.

Gordon, B. (2010). An examination of the responsibility model in a New Zealand secondary school physical education program. Journal of Teaching in Physical Education, 29(1), 21-37.

Grace, M.M., \& Ratcliffe, M. (2002). The science and values that young people draw upon to make decisions about biological conservation issues. International Journal of Science Education, 24(11), 1157-1169.

Halstead, J.M. (1996). Values and values education in schools. In: Halstead, J.M., \& Taylor, M.J., (Eds.), Values in Education and Education in Values. Basingstoke, United Kingdom: The Falmer Press. pp. 3-14.

Halstead, J.M., \& Taylor, M.J. (2000). Learning and teaching about values: A review of recent research. Cambridge Journal of Education, 30(2), 169-202.

Herdem, K. (2016). The Effect of Values Education Activities Integrated with Seventh Grade Science Subjects on Student'Value Development. 
(Unpublished Master's Thesis. Adıyaman University).

Iscan, C.D., \& Senemoglu, N. (2009). Effectiveness of values education curriculum for fourth grades. Education and Science, 34(153), 1-14.

Kelman, H.C. (1958). Compliance, identification and internalization: Three process of attitude change. The Journal of Conflict Resolution, 2(1), 51-60.

Kenan, S. (2009). The missing dimension of modern education: Values education. Educational Sciences: Theory and Practice, 9(1), 279-295.

Kohlberg, L. (1975). The cognitive-developmental approach to moral education. The Phi Delta Kappan, 56(10), 670-677.

Kropp, F. (2006). Values and self-esteem. Asia-Pacific Advances in Consumer Research, 7, 14-18.

Kumarassamy, J., \& Koh, C. (2019). Teachers' perceptions of infusion of values in science lessons: A qualitative study. Research in Science Education, 49(1), 109-136,

Kunduroğlu, T., \& Babadoğan, C. (2010). The effectiveness of values education program integrated with the $4^{\text {th }}$ grade science and technology instructional program. Procedia-Socialand Behavioral Sciences, 9, 1287-1292.

Lee, H., Yoo, J., Choi, K., Kim, S.W., Krajcik, J., Herman, B.C., \& Zeidler, D.L. (2013). Socioscientific issues as a vehicle for promoting character and values for global citizens. International Journal of Science Education, 35(12), 2079-2113.

Lickona, T. (2009). Educating for Character: How our Schools can Teach Respect and Responsibility. New York: Bantam Books.

Living Values Education (LVE). (2012). Living Values Activities for Children Ages 8-14. Association for Living Values Education International, Living Values Education.

Lovat, T. (2011). Values education and holistic learning: Updated research perspectives. International Journal of Educational Research, 50(3), 148-152.

Miles, M.B., \& Huberman, A.M. (2015). Qualitative Data Analysis: An Expanded Sourcebook. $2^{\text {nd }}$ ed. Thousand Oaks, California: Sage Publications.

MoNE. (2018). Science Curriculum (Primary and Secondary School 3, 4, 5, 6, 7 and $8^{\text {th }}$ Grades). MoNE Board of Education and Training Board, Ministry of National Education.

Narvaez, D. (2006). Integrative ethical education. In: Killen, I.M., \&
Smetana, J.G., (Eds.), Handbook of Moral Development. Mahwah: Lawrence Erlbaum Associates, pp. 703-732.

Power, F.C., Higgins, A., \& Kohlberg, L. (1989). Lawrence Kohlberg's Approach to Moral Education. New York: Columbia University Press.

Powney, J., Cullen, M.A., Schlapp, U., Johnstone, M., \& Munn, P. (1995). Understanding Values Education in the Primary School. Reports Express.

Solomon, D., Watson, M., \& Battistich, V.A. (2001). Teaching and schooling effects on moral/prosocial development. In: Richardson, V., (Eds.), Handbook of Research on Teaching. Washington, DC: American Educational Research Association. pp. 566-603.

Superka, D.P., Ahrens, C., Hedstrom, J., Ford, L., \& Johnson, P. (1976) Values Education Sourcebook: Conceptual Approaches, Materials Analyses, and an Annotated Bibliography (ED118465). ERIC. Available from: https://www.files.eric.ed.gov/fulltext/ED118465.pdf.

Tekbıyık, A., \& Akdeniz, A. R. (2017). Fen bilimleri eğitimine değerler eğitiminin entegrasyonu üzerine bir değerlendirme. [An evaluation on the integration of values education to science education]. In: Demirel, Ö., \& Dinçer, S., (Eds.), Küreselleşen Dünyada Eğitim. [Education in a Globalizing World]. Pegem Publications. pp. 129-138.

Thornberg, R. (2008). Values education as the daily fostering of school rules. Research in Education, 80(1), 52-62.

Trevino, L.K. (1992). Moral reasoning and business ethics: Implications for research, education, and management. Journal of Business Ethics, 11(56), $445-459$

UNESCO. (2002). Learning to Be: A Holistic and Integrated Approach to Values Education for Human Development: Core Values and the Valuing Process for Developing Innovative Practices for Values Education toward International Understanding and a Culture of Peace. UNESCO Asia and Pacific Regional Bureau for Education, United Nations Educational Scientific and Cultural Organization.

UNESCO. (1991). Values and Ethics and the Science and Technology Curriculum. Asia and the Pacific Programme of Educational Innovation for Development, United Nations Educational Scientific and Cultural Organization.

Veugelers, W. (2000). Different ways of teaching values. Educational Review, 52(1), 38-46. 


\section{Sample Cases in the DSF}

1. Ömer goes to school by a school bus. When he gets into the bus to go home after school, he realizes that he forgot his science book in the classroom and he has homework to do for tomorrow. He runs to the classroom without telling the driver that he forgot his book in the classroom. He cannot find it on his desk. Anxiously, while searching for his book in the classroom, he remembers that he left the book on his friend's desk, and he quickly takes the book and leaves the classroom. As he goes down the stairs, he sees that the library lamp is on. He worries that he was too late for the school bus. 'What would you do if you were in Ömer's place?'

I would go to the library and turn off the light. Because

I would go to the service quickly. Because

2. Mrs. Büşra is going to cook for her guests in the evening, thus she goes shopping to buy the needs of her house. She remembers that the lamp of the guest room is not working, thus she needs to buy a lamp. She compares two lamps and gets Table 4 below. While thinking about which lamp to buy, she realizes that she doesn't have much money with her and that she has many other things to buy for her guests. 'What would you do if you were in Mrs. Büşra' place?'

\begin{tabular}{lll}
\multicolumn{2}{l}{ Table 4: Lamps and properties } \\
\hline Properties & Lamp A & Lamp B \\
\hline Cost & Low & High \\
Lifetime & Short-lasting & Long-lasting \\
Versatile Light Emission & Not Available & Available \\
Light Efficiency & Low & High \\
Total Electricity Cost & High & Low \\
\hline
\end{tabular}

I would take lamp A. Because

I would take lamp B. Because

3. Betül realizes that tomorrow she has physical education and class and her sportswear is dirty. She tells her mother that her sportswear should be washed. But her mother tells that there isn't enough laundry to run the washing machine and she asks her whether she can wear it without washing. "What would you do if you were Betül?"

I would tell my mother to run the washing machine. Because

I would tell my mother not to run the washing machine and I would wear my sweatshirt at school. Because

4. Yiğit and his older sister go to school on weekdays. Their mother and father are also working, thus there is no one at home on daytime. For this reason, Yiğit's father thinks that the combi boiler is operating in vain during the day, causing him to pay a heavy bill, and he turns the combi boiler off when he leaves the house in the morning then turn it on in the evening. 'What would you do if you were in Yiğit's place?'

I would tell my dad not to turn off the combi boiler and convince him. Because

I wouldn't say anything to my father. Because 